\title{
ANALISIS KETAHANAN PRODUK SOLAR CELL BERBANTUAN SOFTWARE LOGGER PRO
}

\author{
Hamzah $^{1)}$, Moh. Toifur ${ }^{1)}$ \\ ${ }^{1)}$ Program Studi Magister Pendidikan Fisika, Universitas Ahmad Dahlan, Yogyakarta, Jawa Tengah, Indonesia \\ Corresponding author: Hamzah \\ E-mail: hamzahpfis@gmail.com
}

Diterima 01 November 2019, Disetujui 23 November 2019

\begin{abstract}
ABSTRAK
Penelitian ini bertujuan untuk menentukan kualitas solar cell pada nilai fill factor $\left(\mathrm{f}_{\mathrm{f}}\right)$ dan efisiensinya $(\eta)$. Data tegangan $V_{i}$ dan $I_{i}$ diambil secara otomatis menggunakan software logger pro dan menggunakan analisis persamaan eksponensial $y=A e^{-C x}+B$. Data diambil dari solar cell merk polikristal type (99×69) $\mathrm{mm}^{2}$ yang dipaparkan di depan sumber cahaya lampu bohlam philips $100 \mathrm{~W} / 220 \mathrm{~V}$ sejauh $18 \mathrm{~cm}$ pada $\mathrm{Ir}$ sebesar 983, $344 \mathrm{~W} / \mathrm{m}^{2}$. Nilai $P_{\max }$ terbesar besar berada pada sudut kemiringan $30^{\circ}$ sebesar 0,0231 watt. $f_{f}$ yaitu $67 \%$, efisiensi $22 \%$. Pada sudut $30^{\circ}$ tersebut arah cahaya datang tegak lurus dengan bidang solar cell. Sedangkan $f_{f}$ terendah kemiringan $70^{\circ}$ yaitu 0,5362 dan efisiensi $13 \%$.
\end{abstract}

Kata kunci: Fill factor dan efisiensi solar cell; logger pro.

\begin{abstract}
This study aims to determine the quality of solar cell on the value of the fill factor $\left(f_{f}\right)$ and efficiency $(\eta)$. The voltage data $\mathrm{Vi}$ and $\mathrm{li}$ are taken automatically using logger pro software and using exponential equation analysis. The data was taken from polycrystalline solar cell type $(99 \times 69) \mathrm{mm}^{2}$ which was presented in front of the light source of Philips lamp bulb $100 \mathrm{~W} / 220 \mathrm{~V}$ as far as $18 \mathrm{~cm}$ at $\mathrm{Ir}$ of 983,344 $\mathrm{W} / \mathrm{m}^{2}$. The largest Pmax value is at a slope angle of $30^{\circ}$ of 0,0231 watts. $\mathrm{f}_{\mathrm{f}}$ is $67 \%$, efficiency is $22 \%$. At the $30^{\circ}$ angle the direction of the light comes perpendicular to the plane of the solar cell. While the lowest $f_{f}$ is $70^{\circ}$, which is 0,5362 and efficiency is $13 \%$.
\end{abstract}

Keywords: Fill factor and efficiency solar cell; logger pro.

\section{PENDAHULUAN}

Panel surya (solar cell) adalah perangkat yang mengubah energi matahari menjadi energi listrik[1-3].Solar cell ketika pada saat siang/tengah hari yang cerah radiasi matahari mampu mencapai $1000 \mathrm{~W} / \mathrm{m}^{2}, 25^{\circ} \mathrm{C}$ [4-6]. Pada modul sel surya komersial memiliki efisiensi berkisar antara 10\% hingga 30\% tergantung material penyusunnya [7-10]. Solar cell tergantung pada fill factor dan efisiensi konversi energi dan konsentrasi sinar matahari yang diterima oleh panel surya [11-13].

Besaran yang relavan untuk menentukan kualitas solar cell adalah fill factor dan efisiensi sel surya. Fill factor menentukan parameter penyimpanan yaitu kemampuan kerja sel surya yang dinyatakan dalam persen dengan perbandingan daya maksimum $\left(P_{\max }\right)$ yang dihasilkan sel surya terhadap daya teoritis $\left(P_{t h}\right)$.
Sedangan efisiensi $(\eta)$ menentukan persentase output listrik dari sel surya untuk suatu energi yang datang dalam bentuk penyinaran matahari. Efisiensi ini merupakan parameter yang menggambarkan konversi energi dari solar cell.

Untuk mengukur ketahanan atau kualitas produk solar cell menggunakan software logger pro dengan menghubungkan sensor tegangan dan arus pada transducer labquest ditampilkan kelayakan komputer dengan bantuan software Logger pro. Logger pro ini merupakan produk teknologimempermudah dalam eksperimen yang mensimulasi karakteristik arus dan tegangan (I-V) pada percobaan foto voltaik sebagai fungsi tegangan open circuit $\left(V_{o c}\right)$ dan arus short circuit $\left(I_{s c}\right)$.Pengambilan data tegangan-arus dilakukan secara otomatis menggunakan sensor tegangan dan sensor arus loggerpro. 


\section{METODE PENELITIAN}

Prosedur eksperimen

Penelitian ini menggunakan metode eksperimen di Lab. Sensor and Transducer Laborary Magister Pendidikan Fisika Universitas Ahmad Dahlan dengan bantuan komputasi dengan peralatan dan bahan yaitu: Panel surya betergangan 5 volt, lampu sebagai pengganti sinar matahari, kabel penghubung, lux meter untuk mengukur intensitas cahaya, Media/papan sudut kemiringan, busur derajat, komputer, potensiometer, sofware logger pro, labquestmini, sensor tegangan dan sensor arus. Skema alat eksperimen pada gambar 2 .

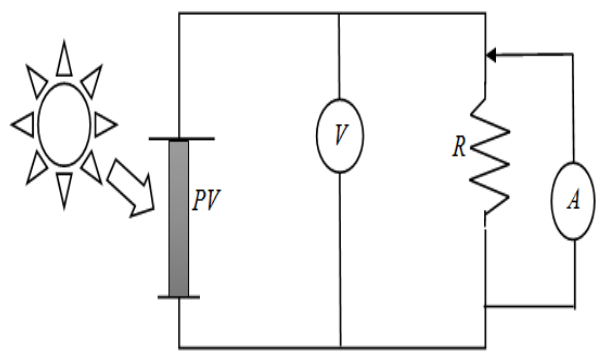

Gambar 1.Skemarangkaian akuisisi data $V$-I

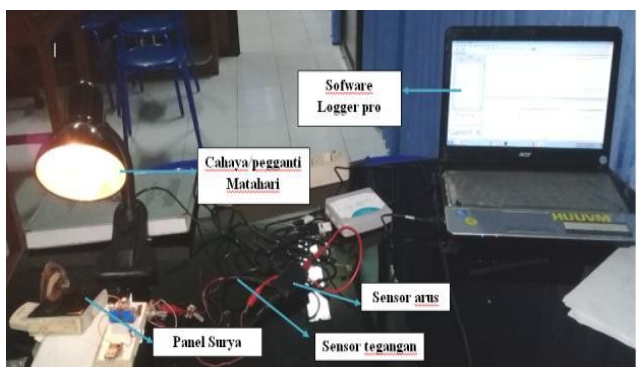

Gambar 2. Prosedur eksperimen

Selanjutnya untuk pengambilan data tegangan-arussolar cell digunakan sensor tegangan dan arus pada logger pro. Selanjutnya membuka layarsoftware logger pro,untuk menampilkan data hasil pembacaan pada sensor. Kemudian mengatur time logger pro, data collection duration 30 seconds and sampling rate 0.2 seconds/sample untuk satu kali pengambilan data. Selanjutnya menghubungkan sensor arus dan tegangan pada libquestmini, kemudian menghubungkan sensor arus positif pada kabel positif solar celldan sensor tegangan dihubungkan dengan kaki 2 potensiometer. Sedangkan sensor arus negatif dan sensor tegangan positif dihubungkan ke kaki 1 potensimeter. Selanjutnya menghidupkan lampubola philips 100W/220V sebagai sumber cahaya dihubungkan pada sumber tegangan PLN. Potensiometer diputar untuk memperoleh nilai sekumpulan $\operatorname{data}\left(V_{i}, I_{i}\right)$.

\section{Metode analisi data}

Nilai $V_{o c}, I_{s c}, V_{\max }$ dan $I_{\max }$ diperoleh darikurva $V$-/hasil fitting data $\left(V_{i}, l_{i}\right)$ menurut fungsi natural exponential,

$$
y=A \exp ^{-C x}+B
$$

dengan, $x=l, y=V$ dan $A, C, B$ merupakan koefesien fitting dari persamaan (7). Nilai $I_{s c}$ diperoleh dari titik potong kurva terhadap sumbu $x$ dan $V_{o c}$ diperoleh dari titik potong kurva terhadap sumbu $y$. Dengan memasukkan $x=0$ pada (7) untuk $I_{s c}$ dan $y=0$ untuk $V_{o c}$ maka diperoleh:

$$
I_{s c}=A+B
$$

Sedangkan persamaan $V_{o c}$

$$
V_{o p}=-\frac{1}{C} \ln \left(\frac{B}{A}\right)
$$

Dengan mengalikan persamaan (8) dan persamaan (9) maka diperoleh nilai daya teoritisnya seperti dinyatakan pada persamaan (1). Daya maksimum diperoleh dari perkalian tegangan $\left(x_{i}\right)$ dan arus $\left(y_{i}\right)$ kemudiandi ambil dari nilai yang paling besar. Sedangkan untuk menentukan intensitas cahaya lampu diperoleh dari persamaan (3) dengan $A$ luas modul solar cell. Adapun penentuan $f_{f}$ solar cell diperoleh dari persamaan (5) yaitu perbandingan daya maksimum dan daya teoritis. Nilai $f_{f}$ dinyatakan dalam persen dan $\eta$ konversi diperoleh dari persamaan (6).

\section{HASIL DAN PEMBAHASAN}

Telah dilakukan analisis ketahanan solar cell menggunakan software logger pro. Pada gambar 3 ditampilkan hasil pengukuran nilai tegangan dan arus logger propada saat $/ r$ sebesar 983, $344 \mathrm{~W} / \mathrm{m}^{2}$. Kemudia dilakukan fitting data menurut fungsi eksponensial seperti pada gambar 3 


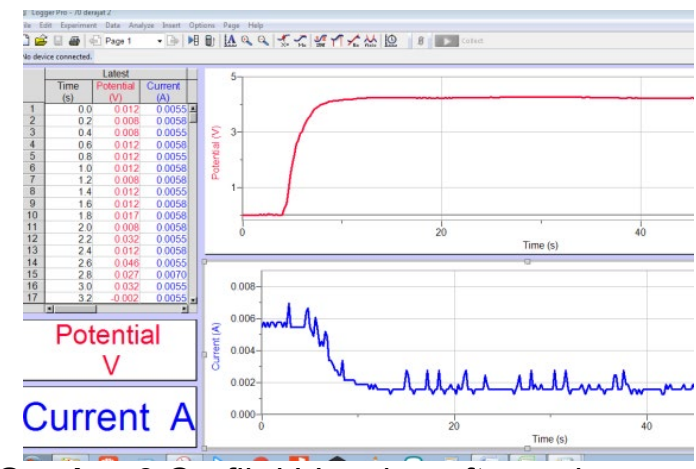

Gambar 3.Grafik V-I pada software logger pro

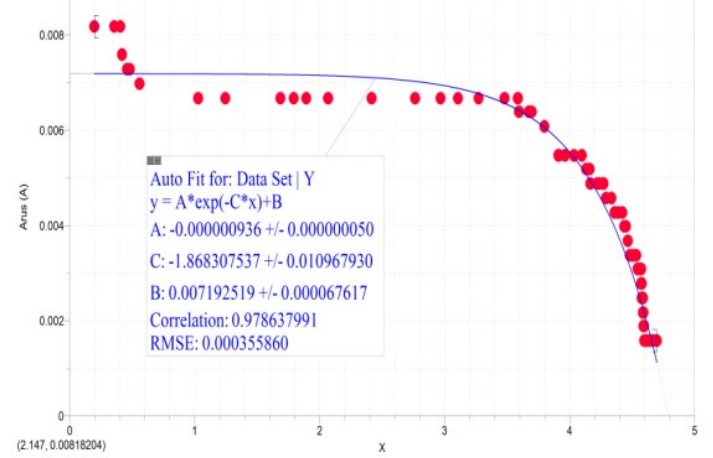

Gambar4. Salah satukurva fitting $V-I$ pada sofware logger pro pada kemiringan panel $30^{\circ}$

Selanjutnya ditampilkan nilai tegangan terhadap arus pada gambar 4 dengan bantuan analisis menggunakan microsoft office excel. Tampak bahwa nilai tersebut tidak sampai memotong sumbu $x$ (tegangan) dan sumbusumbu y (arus). Untuk itu, dilakukan fitting data untuk dapat diekstrapolasikan data menuju ke titik potong sumbu $x$ dan $y$. Sehingga diperoleh $I_{s c}$ dan $V_{o c}$.

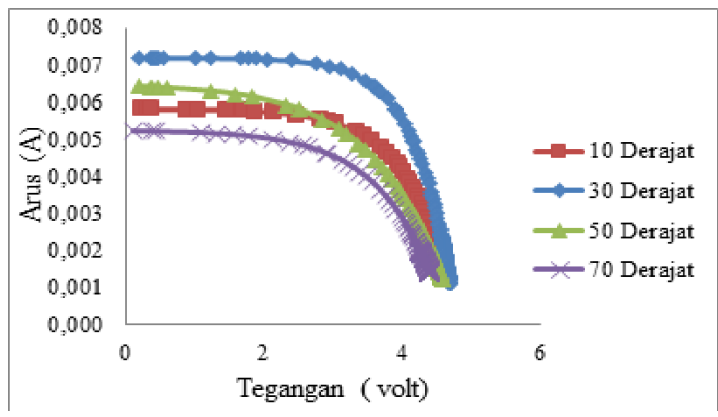

Gambar 5. Grafik hubungan tegangan terhadap arus
Demikian pula nilai $P_{\max }$ pada gambar 5 diperoleh dari nilai $l_{i}$ dan $V_{i}$ pada gambar 6 .

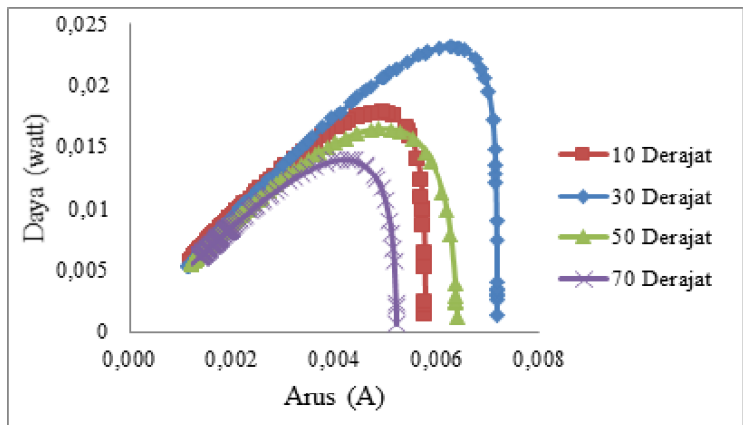

Gambar 6. Grafik hubungan daya terhadap arus

Ternyata, nilai $P_{\max }$ terbesar besar berada pada sudut kemiringan $30^{\circ}$ sebesar 0,02313 watt. Dikarenakan $P_{\max }$ terbesar ketika bidang panel sejajar dengan arah sinar cahaya.Pada variasi penggerak manual untuk modul solar cell nilaiffdan ntertera pada tabel 3 dengan nilai

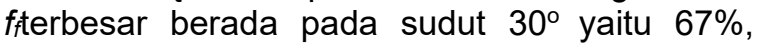
efisiensi $22 \%$. Sedangkan terendah $70^{\circ}$ yaitu 0,53626 , efisiensi $13 \%$.

Tabel 1.Nilai fitting, $P_{t h}, P_{\text {max }}, f_{f}$ dan $\eta$

\begin{tabular}{|c|c|c|c|c|c|c|}
\hline No & Sudut & Fungsi eksponensial & $\begin{array}{c}P_{\text {th }} \\
\text { (watt) }\end{array}$ & $\begin{array}{c}P_{\max } \\
\text { (watt) }\end{array}$ & $f_{f}$ & $\eta$ \\
\hline 1 & $10^{\circ}$ & $y=-3,27\left(10^{-06}\right) \exp ^{(-1,548 x)}+5,78\left(10^{-03}\right)$ & 0,0279 & 0,0177 & 0,6341 & $17 \%$ \\
\hline 2 & $30^{\circ}$ & $y=-9,36\left(10^{-07}\right) \exp ^{(-1,868 x)}+7,19\left(10^{-03}\right)$ & 0,0344 & 0,0232 & 0,6717 & $22 \%$ \\
\hline 3 & $50^{\circ}$ & $y=-5,56\left(10^{-05}\right) \exp ^{(-0,994 x)}+6,46\left(10^{-03}\right)$ & 0,0306 & 0,0164 & 0,5362 & $16 \%$ \\
\hline 4 & $70^{\circ}$ & $y=-1,72\left(10^{-05}\right) \exp ^{(-1,227 x)}+5,23\left(10^{-03}\right)$ & 0,0243 & 0,0140 & 0,5765 & $13 \%$ \\
\hline
\end{tabular}

\section{SIMPULAN}

1. Penggunaan software logger pro sangat baik dan teliti dalam pengukuran untuk menentukan kelayakan produk solar cell.

2. Produk solar cell 5 volt masih layak digunakan dalam kebutuhan kelistrikan pada kapasitas maksimal 5 volt dan telah diuji fill factor $\left(f_{f}\right)$ terbesar $67 \%$ dan efisiensi $(\eta) 22 \%$.

\section{DAFTAR RUJUKAN}

Aliev R., Alinazarova, M.A., Ikranov, R.G., and Ismanova O.T. (2011). The Fill Factor Of Loaded Current-Voltage Performance Of Solar Cells And Its Role For Determining Their Temperature Properties. Applied Solar Energy. 7(2).118-120.

Bhalchandra, V.Cand Sadawarte, Y.A. (2015). "The Factors Affecting The Performance Of Solar Cell", International Journal of Computer Applications (0975 - 8887): 
M-Tech Student B.D.C.O.E. Sewagram Wardha-India

Chegaar, M, Z. Ouennoughi, F. Guechi, dan Langueur. (2003). Determination of Solar Cells Parameters under Illuminated Conditions, Journal of Electron Devices. 2. 17-21.

Das, A. K. (2011). An Explicit J-V Model OfS olar Cell For Simple Fill Factor Calculation, Solar Cell Energy. 85(9). 1906-1909

Erlita. (2014). Energi Supply Solar cell pada Sistem Pengendali Portal Parkir Otomatis Berbasis mikrokontroler AT89S52, https://scholar.google.com /diakses pada tanggal 3 April 2019

Gastineau, J. (1999). Logger pro ${ }^{\mathrm{TM}}$ User's manual. ISBN 0-918731-91-7 (Macintons)

Guliani R., Jain A., and Kapoor A. (2012). Exact analytical analysis of Dye-Sensitized Solar Cell: Improved Method and Comparative Study, There newble energy Journal. 2(2). 549-60

Hamdya, M. Adel. (1994). A New Model For The Current-Voltage Output Characteristics Of Photovoltaic Modules. Journalof Power Sources. 50(1). 11-20.

Maammeur, H. Hamidat, A and Loukarfi, L. (2013). A Numerical Resolution Of The Current-Voltage Equation for a Real Photovoltaic Call, Energi Procedia 36, Fakulti Of Technology, Universitas Hassiba Benbouali, pages 1212-122

Rashmi, S. (2012). Solar Cell, Internasional Journal Of Scientificand Research Publicasions, 2(7). 2250-31536666

Sukandarrumidi. (2016). Energi Terbarukan.Yogyaakarta: Universitas Gajah Mada

Toifur, M., (2013). Perbaikan Penentuan Nilai Fill Factor Sel Surya Dengan Bantuan Fitting Data Dan Teknik Modified Regulafalse", Prosiding Seminar Nasional Penelitian, Pendidikan dan Penerapan MIPA. UN
Yogyakarta: Fakultas MIPA, Universitas Negeri Yogyakarta

Yulinar, A., Khairul, S., dan Assaidah, (2017). Measurement of Solar Panel Output Involving Controller and Reflector. Internasional Journal Energy and Clean Environment. 15(1). 138-142. 